\title{
Paris, Tokyo, Shanghai: Interaction and Communication of Chinese Modern Art
}

\author{
Ruili Qin ${ }^{1, a}$, Zhuo Lin ${ }^{2, b}$ \\ ${ }^{1}$ School of Sociology and Political Science, Shanghai University, Shanghai 200444, China; \\ ${ }^{2}$ School of Fine Arts, Shanghai University, Shanghai 200444, China. \\ aluckli524@163.com, 'linzhuo0406@hotmail.com
}

Keywords: Paris, Tokyo, Shanghai, Interaction, Communication, Modern Art

\begin{abstract}
This paper analyzes the interaction and communication of modern art in Paris, Tokyo and Shanghai in the early 20th century. Paris was the birthplace of modernist art, Tokyo was the first city to receive a western painting in modern Asia and played an important role in nurturing the art of Asian modern art. Chinese artists from Shanghai, went to Tokyo and Paris to study western painting, providing evidence that Shanghai was influenced from Paris and Tokyo from this western painting communication. In addition to the inheriting relationship, international cooperation and interaction were also found. As a matter of fact, the three cities, Paris, Tokyo and Shanghai play an important role in the development of Chinese western painting. Artists were free to create, imitate the trend, exchange ideas and interact, which promoted the development of Chinese modern art.
\end{abstract}

\section{Introduction}

This paper analyzes the interaction and communication of modern art in Paris, Tokyo and Shanghai in the early 20th century. In the late 18th century, the center of European art was transferred from Italy to France. Paris became the birthplace of modernist art. It is undoubtedly an attractive spiritual home that continually attracts artists from all over the world to study and live. As to why Paris has such a strong attraction, Chang Yu said:

You see a mess like me, whose hair is as hard as a hedgehog, with an unshaved face, dirty clothes unchanged for half year, and shoes unable to be buckled. If in China, anyone would regard me as a foreign beggar, and I would never be allowed to enter a snobbery field like Beijing hotel. But in Paris, believe it or not, nine times out of ten, I would be successful when asking a girl wearing a beautiful dress and perfume to dance. And, of course, so did the model. In Paris, who learn art, he always invited a dozen of pretty girls with shiny eyes to be models a year, no matter how poor he is, let alone the broken house. This is the Bohemian life.[1]

For the artist, Paris has a strong artistic atmosphere and generous creative environment, make it an ideal place for artistic creation. Tokyo was the first Asian city to receive western painting and played an important role in nurturing the art of Asian modern art. It's also very attractive to Chinese painters.

I dream of living in Tokyo, the concentration of East Asian culture and a representative of modern East Asian civilization. There are lights on downtown streets, quiet blurred girls. Although Tokyo cannot compare with the Paris' liveliness, London's solemnity or New York's wealthy, but it can be described as a leading metropolis in the backward culture of the East.[2]

The rise of Japanese modern art started in 1876 with the founding of the Technical Fine Arts School (Kobubijutsu Gakkō). In modern times, Japan proceeded its departure from Asia to Europe and the popularization of education, drawn from the western art education system, took the lead in Asian to 
carry out the western painting movement. Japan finally established the center of western painting education after twists and turns.

The Tokyo Fine Arts School and Kawabata School of Fine Arts were the best place to study for Chinese students in Japan. Japan and Europe maintain the communication of art. In Paris, magazines commonly just offered a few copperplate pictures, this remained unchanged for more than a decade., and gave no chance of seeing a colored print. This situation is much worse in Japan. In Paris, everything is simple, and it is difficult to feel satisifed.[3] But the Japanese sophisticated printing industry provided Chinese painters a window to see the trends of the world art.

If we try to illustrate the relationship of the three cities, Paris, Tokyo and Shanghai, and to illustrate the connection of China, Japan and France in modern western art communication, we can focus on a document focusing on Cezanne's works Landscape published in the Chinese art magazine Yi Feng. The works Landscape, created by Cezanne in Paris, was once exhibited at one of the French modern art exhibition works in Tokyo, and it completed the direct spread across space and distance. It was then documented in Yi Feng allowing this piece of modern art to be cross-culturally communicated. After its publication, Chinese artists from Shanghai went to Tokyo and Paris to study western painting, providing evidence that Shanghai was influenced by Paris and Tokyo from this western painting communication. In addition to the following relationship, it showed a relationship of international cooperation and interaction.

\section{The Call for Shanghai from Paris and Tokyo's Modern Art}

Although Paris is far away from Shanghai, but the trend of Paris art, street scenery and even women's fashion have been discussed and mimicked by people in Shanghai. The modern art of Paris was introduced into China in two ways: First, the Chinese western painters who were studying in France, passed information directly from Paris to Shanghai. Second, the Chinese western painters studying in Japan, were introduced indirectly from Tokyo to Shanghai.

During the second European Tour period, Liu Haisu wrote up to 87 articles on the column, European Tour Communication, in the Yishujie, a literary supplement in Shen Daily. In 1931, Wang Yachen introduced the art trends of Paris and Europe by the series of Traveling in Europe in Shen Daily.

There are many other articles on the Beaux-arts de Paris and the art exhibitions of Paris.

Below, a sampling of articles:

Body Sketch in Beaux-arts de Paris:the female model standing on the central stage,surrounded by the students.[4] The Pioneer of Impressionism:Pissarro by Chen Deming.[5] Art Administration of France by Liang Xihong.[6] Fine Arts Schools in Paris , Lectures, Research Institutes and Models by Liang Xihong.[7] A letter About the Latest Parisian Art Circles by Liu Kang.[8] The New Tendency of French Art Circles by Ni Yide.[9] The Letter From Paris by Zhang Ziyu.[10]Talk About Paris:Fauvism and National Crisis by Xiao Shijun.[11] The Pan-Parisization of Modern Art and the Internationalization of Paris Academism by Wu Wan.

One of the documents on the Beaux-arts de Paris published in the magazine Jin $\mathrm{Bu}$ (1913) is the earliest introduction of the Beaux-arts de Paris by Chinese. The special column Modern Art of art magazine Yi Feng, published some articles on the European Art Circles by the Chinese Academy of Art in France on December 1,1936. We can see that Shanghai's media has paid a lot of attention to the Paris art trends at the time.

On the other hand, there also appeared a highly frequent transmission of modern art information between Tokyo and Shanghai. Here's a few examples: 
The most ancient Japanese Western painter of the Meiji era: Kawakami by Liang Xihong.[12] The Anxious and Depressed Japanese Modern Artists by Duan Pingyou.[13] The western painting Exhibition Tour of Japanese imperial by Xie Haiyan.[14] Chinese and Japanese Artists Held a Party Yesterday by Xie Haiyan.[15] International Fine Arts Society Formed at Tokyo by Xu Shiguang.[16] The First Exhibition of Japanese Independent Fine Arts Association by Lin Yong.[17] Three Elements of the Success of Japanese Art Circles by Ye Si.[18] Some Pieces of Views on Japanese Art by Chen Ziyi.[19]

On the 13th, the 7th independent exhibition already held in the Art Museum of Ueno Park in the early spring.This exhibition has a strong flavor of the early spring, with fresh spirit, bright colors, warm tones and tight composition. Many works have their own expression, that make people feel very pleasant. I was deeply impressed by the attractive works, and I spent a few hours at the exhibition, could not bear to leave in the opening day. About my idea of the works, I would like to give to you the detailed description.[20]

Liang Xihong could scarcely contain his delight when he accessed the new art, and then he spread his excitement about the new art to Shanghai through letters. This can be regarded as a direct transmission of Chinese artists' overseas life and study experiences. The communication of western modern art in Shanghai through the magazines, newspapers and other print medias. On the one hand, the artists used print media to promote their own artistic propositions. This also made Shanghai keep pace with Tokyo and Paris in the trends of modern art, and further the communication between Shanghai, Tokyo and Paris.

\section{The Resonance from Shanghai to Paris and Tokyo's Modern Art}

The modern western painting education in China is the process of learning from the west and Japan. Beaux-arts de Paris and Tokyo Fine Arts School, both of which had a tremendous impact on Chinese modern western art education, especially in the art education system, curriculum, teaching and so on. In 1930, the Societe des deux Mondes (an artists group in Shanghai), claimed that it had a level comparable to that of the Paris Academies when recruiting students.

Serving the general hobby artists and offering more research opportunities, and opportunities to create high art. The contents and equipment are similar to French Paris Academies. Everything here is quite perfect. The western painters such as Hu Daozhi, Pang Xunqin, Wang Dilang, Zhou Tai, Guo Guini, Liu Yanren,served as art instructors. Now in practice.[21]

Obviously, the art education in Paris and Tokyo have affected the art education in Shanghai. In addition to Shanghai's academism education on the modern art of Paris and Tokyo, there are also some Chinese painters from Shanghai actively engaged in the modern art world. In the 1920s, in addition to learning new painting skills, some of Chinese painters studying in France were participating in a number of exhibitions through the school's education system. Their works, some of which strictly adhere to the style of their academic education,yet their style of painting and sketches of nature show their realism skills. This is found in the works of Li Chaoshi, Lin Fengmian, Yan Wenliang. Also, the works depicting Chinese themes are often exhibited by Xu Beihong's works Reading Pictures and Yan Wenliang's works Kitchen.

Also, in 1922, Lin Fengmian participated in the Paris Autumn Salon, exhibitioned the works Autumn. In 1924, Lin Fengmian's works The desire of life and Injury Birds was elected to the Paris Autumn Salon. Ms. Fang Junbi's works A Woman Playing Piano was exhibited at the Paris Art Exhibition, won wide applause from the audience. The various newspapers also claimed that Ms. Fang was one of the Orients most well-known painters.[22] Chinese Art Exhibition in Paris: the French government 
collected 12 of the works.[23] In 1924, Ding Yanyong's works selected in the Tokyo Central Art Exhibition. In 1927, Chen Chengbo's works Chia-Yi landscape selected for the Japanese imperial art exhibition. In May 1930, Liu Haisu's works Forest, Night Moon, the shabby room in Erfu Sint Jan Joe and the Rose Village's Early Spring were participated in the Tuileries Salon. [24] June 1, 1931, Liu Haisu held art exhibition in Paris, France. [25] European Tour communication(61th-62th):the process I participated in the Paris Autumn Salon by Liu Haisu.[26] French government purchased Liu Haisu's works snow, and displayed in the National Art Museum Autumn.[27] Wang Ziyun also attracted much attention by the French media during his studies in France.[28] In 1931, Lu Sibai's works were selected for the Paris Spring Salon. In 1931, Yang Sanlang's works were selected for the Paris Autumn Salon. In 1933 and 1934, Huang Xianzhi's works were selected for the Paris Spring Salon. In 1933, Qin Xuanfu's works were selected for the Paris spring salon. In 1934, Qin Xuanfu's works were selected for the French Independent Salon. In 1932, Lu Sibai's works won the Spring Salon Honor Award of Lyon, France. In the spring of 1935, Chang Shuhong was elected for one of the Paris Artists Association super-elected members to participate in the French Paris Portrait Association. He held oil painting exhibitions in Paris, display more than 50 works. October 4, 1934, the exhibition Revolution of Chinese New Art was held at the Pierre Worms Gallery in Paris. The spring of 1935, Chang Shuhong's works Sisters participated in the Paris Spring Salon and won the Gold medal. Jin Xuecheng's works have been selected for the 22nd Nikaten of Japan.

The reason why I cited so many Chinese artists in Tokyo and Paris that participated in the art exhibitions is that I want to prove that the Chinese artist were both studying and working and during their time abroad and actively communicated with foreign artists. While the activities of Chinese artists in Paris and Tokyo did not create great repercussions around France and Japan, but in Shanghai and even China, it inspired numerous Chinese artists and promoted the Chinese modern art movement.

Chinese artists also held some western paintings overseas. For example, the exhibition of Hangzhou Art College, held in Tokyo, the exhibition of ten Chinese Painters visiting in Japan held in Tokyo on July 31, 1934, and the exhibition of Chinese students Studying in Tokyo,Japan.[29]

Another way the Chinese artists responded to the modern art of Paris and Tokyo is that they established art associations overseas and held exhibitions. In April 1924 , Liu Haisu, Wang Yachen, Fang Junbi and others in France to set up Chinese Associations of Art in France. In January 1933, Chang Shuhong organized the largest Chinese artists organization overseas, Chinese Academy of Art in France in Paris, which held 16 art seminars and published journals.

The art exhibitions of Wang Jiyuan, more fully illustrate the relationship between the three cities of Paris, Tokyo and Shanghai. According to statistics, Wang Ji Yuan held 10 exhibitions from 1926 October to 1932 July, of which six were held in Shanghai, three in Tokyo, one in Paris.

It was the surprise that the high frequency of the exhibitions and the places was wide-ranging. In 1931, Charles Fegdal evaluated the works of Wang Jiyuan through the perspective of Westerners, published in the Paris Weekly:

The exhibition of Chinese painter Wang Jiyuan has its real specialty. Sometimes he tried to study European painting techniques, judging from the vivid light and shade effects as the impressionism and the extreme architectural style as the analysism, which has left this time quite far. But when he went with the inner flow and let his oriental nature take the lead, he was even more touching with the Asiatic soul. His watercolors and sketches expresses a poetic charm as visionary as from a fantastic wonderland. This Chinese artist leads us to a artistic atmosphere with a exotic mood.[30] 
Wang Jiyuan showed the unique value of Chinese western paintings in the 1930s through demonstrating work distinctly oriental qualities. The Chinese Independent Fine Arts Association was established by Liang Xihong, Zhao Tso, Zeng Ming, and others Chinese artist studying in Japan in 1934. The main purpose is to imitate surrealism, against the imitation of reality, to encourage independent artistic creation. It has held many exhibitions in Tokyo, Guangzhou, Shanghai, and Nanjing.

The first exhibition was held in Guangzhou in March 1935, and had an international group of artists. Chinese painters Liang Xihong, Zeng Ming, Zhao Tso and Li Dongping, as well as the French painter Audre Beseind, the Japanese painters Mihiko Masatoshi, Kanehara, Fukuoka Teutaro and Ota Tribute all attended. The Second exhibition was held at the end of 1935 in Shanghai, and continued of the modernist spirit of the Japanese Independent Art Association. The works of the presented a strong diversity and modernist style.

\section{Shanghai artists' permanent dream for Paris}

In the 1930s, the Chinese painters studying in Europe returned to China gradually and became the main force of the Chinese western painting circles. The Storm Society, was formed and by a group of these artists who possessed a pioneering spirit in Shanghai, closely related to the Paris Art Circle.

The artists of Storm Society studied various artistic styles, refined the essence of famous works of various countries, combined with their talents, created a unique look. The annual large-scale exhibition was very exciting, until the war began.[31]

Although those artists may have returned from Paris to Shanghai, but did so with the bustling Paris, and its shaking images, still embedded in their memory. Fu Lei wrote in The Dream of Pang Xunqin: Pang Xunqin was impressed by everything in Paris, so that the works created in Shanghai, is still with the taste of Paris.[32]

Ni Yi-de described Pang Xunqin in the article The Group of the Storm Society:When he returned to China, he maintained a style of Paris artist.Wearing a black velvet coat, hat obliquely in the side, his hands inserted in his pants pocket, long and disheveled hair, and mouth always wearing a pipe......He always remembered his artistic life in Paris.[33]

Pang Xunqin newly returned to China from Paris, cannot forget the life of Paris. In the middle of the night, all the voices on the streets disappeared, familiar pictures of Paris began to emerge in his mind. He took out the paint brush, painted directly on the canvas with the familiar streets of the mind, the familiar color, and painted vividly until a picture was born.[34]

Therefore, Pang Xunqin creative works follow the Parisian theme, such as This is Paris and Cafe both depicting life in Paris. At the same time, the foreign artists came to China to hold exhibitions and Communicate art, illustrating the relationship between the three cities of Paris, Tokyo and Shanghai.

\section{Conclusion}

In the 1930s, the Chinese painting movement no longer rigidly adhere to the self-development and communication of Shanghai due to the wide variety of media. It showed the Interaction and Communication relationship between the three cities of Shanghai, Paris and Tokyo. It includes three aspects: art education reference, art creation interaction and art information communication.

As a matter of fact, the three cities Paris, Tokyo and Shanghai play an important role in the development of Chinese Western painting. Artists were free to create, imitate the trend, exchange ideas and interact, which promoted the development of Chinese modern art. 


\section{References}

[1] Ni Yide, The Art Circle ,Liang You Book Printing Company, Shanghai ,1936.

[2] Ni Yide, From Shanghai to Tokyo, Journal of Tourism, winter number(1927) .

[3] Wang Ziyun, Paris Communication, Yi Feng.8 (1935) 36.

[4] Information on Weekly of Shi Bao Photo Supplement.167(1923).

[5] Information on Shen Daily. September 23(1930).

[6] Information on Journal of Fine Arts(1937 Shanghai),4(1937) ,76-79.

[7] Information on Journal of Fine Arts(1937 Shanghai),3(1937),66-69.

[8] Information on Shen Daily. January 13,15(1932).

[9] Information on Shen Daily. May 11(1933).

[10]Information on Journal of Yi Lang ,1(1946) ,24-26.

[11]Information on Shen Daily. March 14(1933).

[12] Information on Journal of Fine Arts(1937 Shanghai),2(1937) ,29-30,35-36.

[13] Information on Journal of Nei Wai ,5(1936), 6-9.

[14]Information on Shen Daily. January 17(1930).

[15]Information on Shen Daily. January 17(1930).

[16]Information on English Weekly,638(1928),795.

[17]Information on Shen Daily. January 24(1931).

[18] Information on Journal of Yi Lang ,4(1930),23.

[19]Information on Journal of Yi Lang ,4(1930) ,21-23.

[20]Liang Xihong,A letter from Tokyo,Journal of Fine Arts(1937 Shanghai),3(1937),69-70.

[21] Societe des deux Mondes A Society for research Western painting, Shen Daily. September 22(1930).

[22] Information on Shi Bao Photo Supplement.362(1927),3.

[23] Information on Liang You.82(1933),31-32.

[24]Liu Haisu,European Travel Essays,China Book Company,Shanghai,1935.

[25]Information on Shen Daily. May 30(1931).

[26] Information on Shen Daily. July 2,6(1931).

[27]Information on Shen Daily. September 19(1931).

[28]Zhao Li, Yu Ding,Chinese oil painting literature (1542-2000),Hu Nan Fine Arts Publishing House,Changsha,2002,p.617.

[29] Information on Shen Daily. June 25(1931).

[30] Information on the album of Wang Jiyuan's art exhibition in 1933.

[31] Information on The Arts and Life.7(1934).

[31]Fu Lei, The Dream of Pang Xunqin,Art Trimonthly,3(1932).

[32]Ni Yide, The Art Circle ,Liang You Book Printing Company, Shanghai ,1936.

[33] Information on The Times.3(1931). 